\title{
Bispecific Antibody MDX447
}

National Cancer Institute

\section{Source}

National Cancer Institute. Bispecific Antibody MDX447. NCI Thesaurus. Code C2207.

An antibody with potential antineoplastic activity. Specific for both the high-affinity immunog lobulin G (IgG) receptor CD64 and epidermal growth factor receptor (EGFR), bispecific antibody MDX447 may enhance cellular immune responses against EGFR positive cells, resulting in increased tumor cell lysis. (NCI04) 